\title{
IMPROVING THE STUDENTS' ABILITY TO WRITE DESCRIPTIVE TEXTS THROUGH FOUR SQUARE WRITING METHOD
}

\author{
Ilmiah, Supardin, Hasnawati Latief \\ English Education Department, Faculty of Teacher Training and Education \\ Universitas Muhammadiyah Makassar \\ Muhammad Basri D \\ English Language Studies, Universitas Muslim Indonesia \\ ilmiah@unismuh.ac.id
}

\begin{abstract}
Writing is a difficult skill for the students at SMPN 26 Makassar. It could be seen from the result of diagnostic test which showed the ability of the second year students of SMPN 26 Makassar in writing paragraphs was still poor. The students were unable to express their ideas well in making descriptive texts. The research used Classroom Action Research that consisted of planning, action, observation and reflection. It conducted in two cycles in which each cycle comprised four meetings. The subjects of this research were 28 students of the second year students of SMPN 26 Makassar. The findings indicated that the students' ability to write descriptive text in cycle 1 have not reached the score target because the mean score of the students were 66.52 that classified as "fairly good" whereas, In cycle 2 the students' mean score were 75.26. It indicated that the score target has been reached and classified as "Good". Therefore, the researcher suggested the English teacher to apply Four Square Writing Method as one of the alternative ways in teaching writing subject in the classroom especially in teaching descriptive text.
\end{abstract}

Keywords: Writing Ability, Descriptive Text, Four Square Writing Method

\section{INTRODUCTION}

In this globalization era, English become global language that most used in every field and activity in the world that influences every human activity such as communication, education, tourism, culture and technology. It makes every people try to master English to follow world moving. It happens not only in social life but also in educational programs.

Government to support educational program in Indonesia has taken English as one major subject in the school because English in Indonesia is also used as an international medium of communication, science and technology and 
used as sources for lexical development of Indonesia as a modern language (Lowenberg, 1991).

English language consists of four skills, namely speaking, listening, reading, and writing. The other elements are grammar, vocabulary, and pronunciation. These elements are expected to enable students to master the language quickly. English language can be expressed whether in oral or written. However, these two kinds of communication have different aspect. In oral communication can be understood directly while doing communication, but for written communication, it has some element or component that should be paid attention well in order to understand easily and no ambiguous. Therefore, writing is one the most important basic skills that should be learned well. And writing is one of the language skills that plays important role in human communication in which enable human being to communicate and express their feelings and opinions. (Pincars, 1987: IV).

There is no doubt that English writing is important as the other three language skills namely listening, speaking and reading. The ability to write frequently demanded in many occasions in our life. For many reasons writing skill is crucial to most people. In relation about that, Adelstein and Vipal (1980) express that in all subjects in our life or in all professions, the ability to write or express oneself clearly essential basic for success. Writing is crucial means of communication that used to communicate with other people in society and to express our feeling and opinion.

Additionally, writing is a process allowing writer to explorer thoughts and ideas, and make them visible and concrete. Writing encourages thinking and learning. It motivates communication and makes thought available for reflection (Sangkala, 2012).

Writing means also how to communicate our opinion to another person on the paper. But in fact, it cannot be done easily because it is very difficult to express. Furthermore, Heaton (1984:126) states that in writing we need a good idea in producing a composition or written material. In other words, if students do not have good ideas they will be bored with it. For writing subject, the students 
must acquire ideas about what they have to choose one theme and then decide one topic and also find the appropriate words to express the ideas. Many students still encounter difficulties in writing because it is complex and difficult. In studying English, many students who study in the tertiary level still often make many errors in writing although they have learned it for many times, even years.

In relation to the important of the material, the researcher has an alternative to use Four Square Writing Method to help the students to express their ideas into written form which sometimes they have a limited idea so their writing cannot run well. So through this method, the students can express their ideas easily.

Four Square Writing Method means that how to organized well. To make clearly, Gould (1999) states that four square writing method is a unique method to teach basic writing skills and the method is a great way to learn to write.

\section{CONCEPT OF WRITING}

There are some factors that influence the students' ability to write; they are the vocabulary, the interesting topics given, the interest of students in learning writing such as picture, map, graphic, etc. and the time to teach writing in English course or inappropriate technique (Syam, U. K., \& Sangkala, I. 2014).

Lindbolm in Fatmawaty (2010:13) gives definition of writing as studying to focus our mind on important matters, and learning about them. By this activity, a person can find the solution of difficult problem, master the fact even by writing, a person can also communicate their mind that cannot be done through other ways. We can say that writing is the act of expressing something through the application of language system. So, when we write, there are two problematic areas namely "what to write and how to write it". It is then understandable that language skills are meant as the ability to manipulate the rules of language conventionally, while extra linguistic system or knowledge of the world refers to what the writer knows about the subject to write.

Another statement about writing skill comes from Bram, (1995:3) stated that writing is producing written message which is an active process to organize 
and formulate the ideas on the paper. Therefore, before we write we need to determine what the writer shall have something meaningful to convey.

In addition, Byrne (1984:1) states that writing is the act of forming graphic symbols, that is letter or combination of letters in which relate to the sounds when the writers make in speaking. In this sense, the symbols have to be arranged according to certain convention, to form words, and words have to be arranged to form sentences.

Furthermore, Good in Yuharniaty (2002:6) states that writing is the graphic representation of a language that follows some systematic order; pictures or graphic symbols are not considered a form of writing unless they form part system that can be grasped by the reader familiar with the system.

Based on definition above the writer can conclude that writing is one of language skills in English that used to express ideas. In writing, the writer will be involved in the process of building the larger units of ideas from the larger ones. These will be linked to a form a piece of paragraph which will be also linked together to form a larger unit of writing, that is a piece of composition.

\section{The Forms of Writing}

The forms of writing are divided into five divisions' namely narrative, descriptive, recount, expository and argumentative.

\section{a. Narrative}

Narrative is the form of writing used to relate the story of acts or events. It places occurrences in time and tells what happened according to natural time sequences. Types of narrative include short stories, novels, and new stories, as well as large part of our everyday social interchange in the form of letters and conversation (McDougal, Littlell \& Company, 1999:104).

b. Descriptive

Descriptive reproduces the way things look, smell, taste, feel, or sound. It may also evoke moods, such as happiness, loneliness, or fear. It is used to create a visual image of people, places, even of units of time-days, times of day, or seasons. It may be used also to describe more than the outward appearance of people. It may tell about their traits of character or personality. 
Good description usually has three important qualities. These have a dominant impression supported by specific details, a clearly recognizable mood, and logical development (Wishon and Burks 1980: 128-129).

c. Recount

Recount is a text which retells events or experience in the past. Its purpose is to retell events. The generic structures of recount are orientation-events-reorientation. It has a similarity with the generic structures of narrative. The differentiated of recount text with narrative text only is in events. There is no complication in recount.

\section{d. Expository}

Expository is used in giving information, making explanations, and interpreting meanings. It includes editorials; essay, and informative and instructional material. Used in combination with narrative, exposition supports and illustrates. Used apart from narrative, it stands alone as an essay.

\section{e. Argumentative}

Argumentative is used in persuading and convincing. It is closely related to exposition and it is often found combined with it. The aim is to make a case or to prove or disprove a statement or proposition. It may present arguments to persuade the reader to accept an idea or a point of view.

\section{CONCEPT OF FOUR SQUARE WRITING METHOD}

Four Square Writing Method is a method of teaching basic writing skill that can be applicable accross grade levels and curriculum areas in which concerns narrative, persuasive, descriptive and expository form of writing (Gould, 1990).

Four Square Writing Method is an instructional tools that can help students organize information and promote thingking about relationship between concepts. Furthermore, the spatial arrangement of four square writing method namely in graphic organizer allows the students and the teacher to identify missing information or absent connection in one's strategic thingking (Ellis, 2004). 
Four Square Writing Method is a simplified graphic organizer for teaching writing to children in school because it allows students to use their own thinking and then reflect, revise and re-organize their knowledge strategies (Lester, 2007).

\section{The Criteria of Four Square Writing Method}

Gould, (1999) states that Four Square Writing Method is primarily a visual framework for assisting students with formulating ideas in an organized manner prior to writing an essays in which it works as follows:

a. A rectangle is drawn, width exceeding height, and divided into four smaller rectangles of equal size. An additional rectangle is drawn in the center of the figure, taking some of the area in each of the other four rectangles. A total of five rectangles are thus created.

b. The students write a complete topic sentences in the center rectangle.

c. The students then write sentences in the lower-left, upper-left, and upper-right rectangles that develop the thesis of the central topic.

d. Finally, the students write a summary sentence in the lower-right rectangle. The summary sentence describes how the reader is intended to feel about the topic.

\section{The Benefits of Using the Four Square Writing Method}

There are many advantages of in using Four Square Writing Method namely:

a. It helps organize thoughts/plans before writing

b. it can be applied to expository, descriptive, persuasive, and narrative forms of writing

c. Visual and kinesthetic aid to help students focus writing, provide detail, and enhance word choice

d. It can be modified to meet students needs.

\section{RESEARCH METHODOLOGY}

This research used classroom action research (CAR) that consisted of planning, action, observation and reflecting. It conducted in two cycles each cycle comprises four meetings. Cycle one was to observe the students' competence in writing by using writing process approach. After finding the result of cycle one, the researcher would continue to the second cycle to improve the prior cycle. 




\section{Indicators}

The indicators of this research used to measure the variables (content and organization). The indicators of content were unity and completeness especially in making descriptive texts. For the indicator unity, it means that all the sentences must related to the main idea. In other words, all the sentences included in the writing must support the main idea of the topic sentences. Whereas, completeness means that all the sentences in the paragraph must be organized well based on the pattern there was introduction, development of idea and conlusion. Meanwhile, for indicator coherence means that all the paragraphs must be sticked together. In other words, all the paragraphs must be interrelated one another. Whereas, spatial order means that how far all the sentences put in the appropriate orders to show a clear understanding. 


\section{Research Instruments}

In this section, the researcher uses two instruments for collecting data:

1. Test

The test used to know the students' improvement to write persuasive texts through Four Square Writing Method. The test which has been given before action of cycle I started. It is considered as the diagnostic test. At the end of each cycle, the test was given to measure the students' improvement.

2. Observation

It aims to find out the students' activeness during writing learning process in the classroom through Four Square Writing Method.

\section{DISCUSSIONS}

\section{The improvement of the students' writing descriptive text in content}

The researcher found out the improvement of the students' writing ability in content by using Four Square Writing Method in diagnostic test, cycle I and cycle II and the improvement are presented in the following table.

Table 1 : The Improvement of the Students' Writing Descriptive in Content

\begin{tabular}{|c|c|c|c|c|c|c|c|}
\hline \multirow[t]{3}{*}{ No } & \multicolumn{7}{|c|}{ Content } \\
\hline & \multirow[t]{2}{*}{ Indicators } & \multirow{2}{*}{$\begin{array}{c}\text { Diagnos } \\
\text { tic Test } \\
\text { Mean } \\
\text { Score }\end{array}$} & \multirow{2}{*}{$\begin{array}{l}\text { Cycle } 1 \\
\text { Mean } \\
\text { Score }\end{array}$} & \multirow{2}{*}{$\begin{array}{l}\text { Cycle } 2 \\
\text { Mean } \\
\text { Score }\end{array}$} & \multicolumn{3}{|c|}{ Improvement (\%) } \\
\hline & & & & & DT-C1 & $\mathrm{C} 1-\mathrm{C} 2$ & DT-C2 \\
\hline 1 & Unity & 53.07 & 66.46 & 75.64 & 25.23 & 13.82 & 42.52 \\
\hline \multirow[t]{3}{*}{2} & Completeness & 53.21 & 66.78 & 74.53 & 25.50 & 11.60 & 40.06 \\
\hline & $\sum x$ & 106.28 & 133.24 & 150.17 & 50.73 & 25.42 & 82.58 \\
\hline & $\bar{X}$ & 53.14 & 66.62 & 75.08 & 25.36 & 12.71 & 41.29 \\
\hline
\end{tabular}

The table above proves that the use of Four Square Writing Method in teaching and learning process is effective to improve the students' writing ability especially in descriptive text. The table above shows that the students' achievement in cycle II is highest than in cycle 1 and diagnostic test and also the improvement of students' writing descriptive text in content in cycle II is highest 
and the improvement of the students' in content from diagnostic - test to cycle II is 41.29 .

To see clearly the improvement of the students' ability to write descriptive text in content, the following chart is presented.

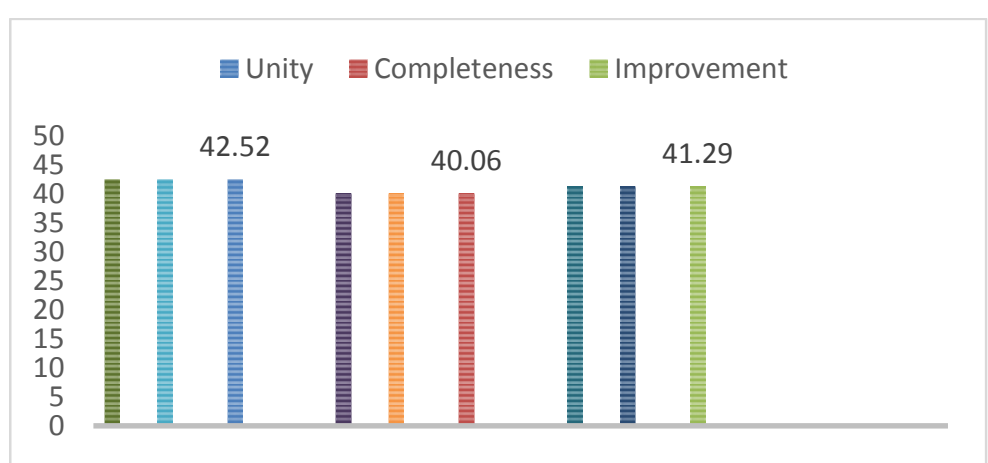

Figure 1. The students' improvement in content

The chart above show the improvement of the students' writing descriptive text in content after evaluation in cycle I and cycle II, there is significant improvement of the students' writing descriptive in unity and completeness where the result of unity is 42.52 , completeness is 40.06 and the improvement is 41.29

\section{The improvement of the students' writing descriptive text in Organization}

The aplication of Four Square Writing Method in writing descriptive text the writer found that the mean score of organization is dealing with coherence and completeness. The improvement of the students' writing organization dealing with coherence and completeness at the second year students of SMPN 26 Makassar can bee seen clearly in the following table :

Table 2: The Students' Improvement In Organization

\begin{tabular}{cccccccc}
\hline No & \multicolumn{6}{c}{ Content } \\
\cline { 2 - 8 } & Indicators & $\begin{array}{l}\text { Diagnostic } \\
\text { Test }\end{array}$ & Cycle 1 & Cycle 2 & \multicolumn{2}{c}{ Improvement (\%) } \\
\cline { 2 - 8 } & $\begin{array}{l}\text { Mean } \\
\text { Score }\end{array}$ & $\begin{array}{l}\text { Mean } \\
\text { Score }\end{array}$ & $\begin{array}{l}\text { Mean } \\
\text { Score }\end{array}$ & DT-C1 & C1-C2 & DT-C2 \\
\hline $\mathbf{1}$ & Coherence & 53.21 & 65.96 & 75.28 & 23.96 & 14.12 & 41.47 \\
\hline $\mathbf{2}$ & Spatial order & 52.85 & 66.89 & 75.60 & 26.56 & 13.02 & 43.04 \\
\hline & $\sum x$ & 106.06 & 132.85 & 150.00 & 50.52 & 27.14 & 84.51 \\
\hline & & 53.03 & 66.42 & 75.44 & 25.26 & 13.57 & 42.25 \\
\hline
\end{tabular}


The students' ability in organization also improves from diagnostic test in cycle I namely 53.03 to 66.42 and cycle II is 75.44 . The table above shows that there is significant improvement of the students' writing desciptive text in organization aspect after taking action in cycle I and cycle II through the aplication of Four Square Writing Method. The improvement the students' writing organization aspect, the following figure is presented:

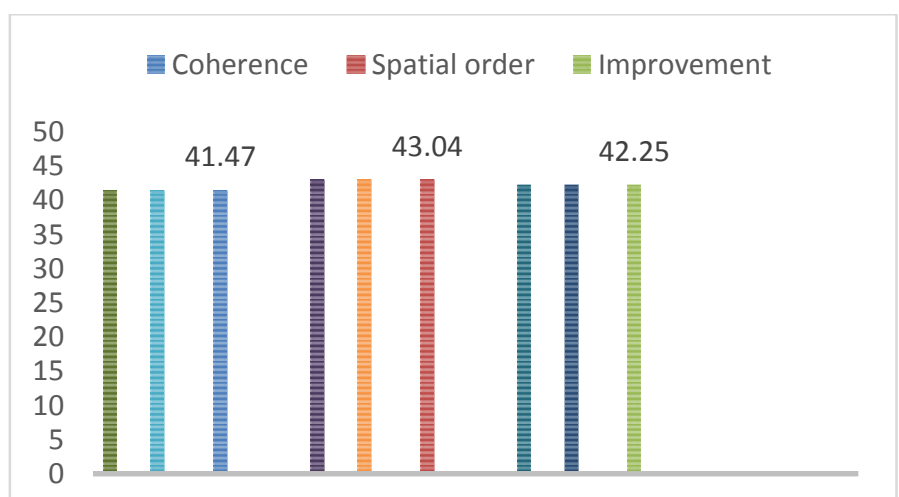

Figure 2: The The students' improvement in organization

The chart above show the improvement of the students' writing descriptive text based on the organization aspect after evaluation in cycle I and cycle II, there is significant improvement of the students' writing descriptive in coherence and spatial order. where the result of coherence is 41.47 , spatial order is 43.04 and the improvement is 42.25 .

\section{The Improvement of the Students' Writing Ability}

The aplication of Four Square Writing Method in improving the students' writing descirtive text in indicators of coherence and spatial order is enable to improve the students' ability to write descriptive texts. The improvement of the students' writing ability that dealing with coherence and spatial order can bee seen clearly in the following table :

Table 3. The Improvement of the Students' Writing Ability

\begin{tabular}{cccccccc}
\hline No & & \multicolumn{4}{c}{ Content } \\
& Variables & $\begin{array}{l}\text { Diagnostic } \\
\text { Test }\end{array}$ & Cycle 1 & Cycle 2 & \multicolumn{3}{c}{ Improvement (\%) } \\
\cline { 2 - 7 } & Mean Score & $\begin{array}{l}\text { Mean } \\
\text { Score }\end{array}$ & $\begin{array}{l}\text { Mean } \\
\text { Score }\end{array}$ & DT-C1 & C1-C2 & DT-C2 \\
\hline $\mathbf{1}$ & Content & 53.14 & 66.62 & 75.08 & 25.36 & 12.69 & 41.28 \\
\hline $\mathbf{2}$ & Organization & 53.03 & 66.42 & 75.44 & 25.24 & 13.58 & 42.25 \\
\hline
\end{tabular}




\begin{tabular}{lllllll}
\hline$\sum x$ & 106.17 & 133.04 & 150.52 & 50.6 & 26,27 & 83.53 \\
\hline $\bar{X}$ & 53.03 & 66.52 & 75.26 & 25.3 & 13.13 & 41.76 \\
\hline
\end{tabular}

The table above proves that the use of Four Square Writing Method in teaching and learning process is table is able to improvement of students' writing ability after taking action in cycle I and cycle II where the students' achievement in cycle II is highest and the improvement of the students'writing ability from diagnostic test to cycle II 41.76

To see clearly the improvement of the students' writing ability in the folllowing figure :

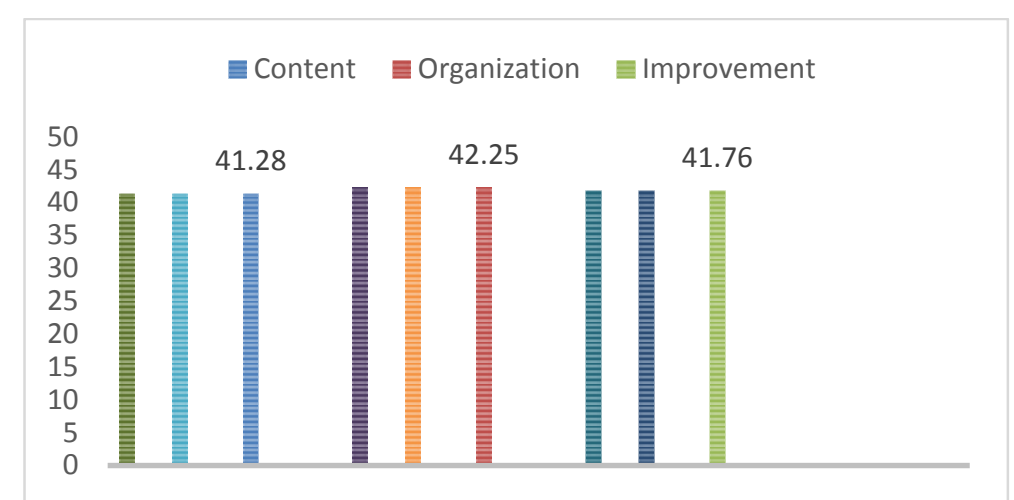

Figure 3: The Improvement of the Students' Writing Ability

The figure above shows the improvement of the students' writing ability in content and organization. The students' improvement in content is 41.28 while in organization, the students' improvement is 42.25 . So, the mean score of the students' improvement is 41.76

The research findings indicates that the students skill in writing text improved by Four Square Writing Method, the description result of writing test showed that the students skill in writing text through Four Square Writing Method.

The improvement of the students' writing ability to write descriptive texts in content and organization by using Four Square Writing Method makes the students' ability effectively improved. Where the researcher finds that before Using Four Square Writing Method the students' means score in diagnostic test is 53.14 and the score is categorized as fair. The means' score of the students in cycle II is 75.26. It is improved and showed that the score in good classification. 
The researcher analyzes that using Four Square Writing Method can improve the students' ability to write descriptive texts. It proved by the students' mean score in cycle I and cycle II higher than the students' mean score in diagnostic test.

For clear explaination about the finding above, the researcher describes the finding above completely namely:

\section{The improvement of the students' writing descriptive text in content}

There is an improvement of the students' ability to write descriptive texts by using Four Square Writing Method in content where the researcher finds that in the diagnostic test the students' mean score is 53.30. It means that it still afar from the target. However, after implementing Four Square Writing Method in cycle I the students' mean score becomes 66.43 . The research taught about the text in the cycle I through Four Square Writing Method. The research found that the students' got difficulties in writing text especially, in grammar and expressing and develop their ideas into written form. Finally, the content that they write in their writing was not clear for the reader.

The difficulty of the students' in writing had been analyzed, so the researcher thought the problem solving. And then, the research decided to do the cycle 2 by doing the revision in the lesson plan which prepared in revision planning of cycle 2. The result of revision planning to resolve the students' difficulties in getting ideas was in writing activity the researcher gave them some topic then they had to choose one of them beside that the reseacher also explain about the grammar. It was done to avoid the reception in learning and teaching process.

\section{The improvement of the students' writing descriptive text in organization}

Implementation Four Square Writing Method in the class, the researcher found that the mean score in cyle 1 the students just got 6.45 and in cycle II is 7.35 .meanwhile the target score is 75 . It means that the target score could be achieved in cycle II.

The researcher taught the text in cycle 1 by using Four Square Writing Method, the researcher found that the students' had difficulty to organize well 
their idea in form of text, they were still confused in organization elements of writing and when they wrote text the first sentence and the next sentence was not connected. The text consist of topic sentences, supporting sentences and concluding sentence but the students' cannot make all the supporting sentences and connect their text so their text still make confusion for the reader.

Based on the unsuccesful teaching in the cycle I, the researcher decided to do cycle 2 . In cycle 2, the researcher revised the lesson plan and the researcher should explain more clearly, if needed gave the students' occasion to ask about the material. Besides that, the researcher had to give better guidance for the students' in organizing their idea.

\section{The Improvement of the Students' Mean Score}

The researcher concludes that the students' writing mean score based on the elements of organization and content in cycle 1 is 66.52 and in cycle II is 75.26. It means that the mean score gets improvement as 41.76. Therefore, the target that had been said in the caphter 1 could be achieved. The researcher may say that teaching writing descriptive text by using Four Square Writing Method is a good way to improve the students' ability to write descriptive texts.

\section{Observation Result}

The improvement of the students' activeness during the learning process. In cycle I the students' activeness in the $1^{\text {st }}$ meeting is $47.324 \%$, the $2^{\text {nd }}$ meeting is $52.78 \%$, the $3^{\text {rd }}$ meeting is $60.71 \%$ and the $4^{\text {th }}$ meeting is $72.42 \%$. In cycle II, the students' activeness in the $1^{\text {st }}$ meeting is $51.78 \%$, the $2^{\text {nd }}$ meeting is $60.71 \%$, the $3^{\text {rd }}$ meeting is $72.42 \%$ and the $4^{\text {th }}$ meeting is $81.25 \%$. Based on the interpretation of the table and the graphic above indicate that the activeness of students in learning process always grow up from the first meeting in cycle I. In the first meeting of cycle II students probably get bored of material so their activeness decrease but researcher tried to engage them. It made their activeness increased again until the last meeting in cycle II. 


\section{CONCLUSIONS}

Based on the analysis of findings, it can be concluded that:

1. Using Four Square Writing Method can improve the students' ability to write descriptive text in variables of content and organization. By using the method, the researcher finds that there is a significant improvement of the students' ability to write descriptive texts.

2. Teaching descriptive texts by using Four Square Writing Method gives positive impact to the students' mean score namely from the students' mean score which classify as fair becomes good.

3. Using Four Square Writing Method in teaching descriptive text is able to improve the students' activeness during the learning process in the classroom.

\section{BIBLIOGRAPHY}

Adelstein, M. E. Pival, J. G. 1980. The Writing Commitment. New York: Hartcount Brace java Novich. Inc.

Ahmad, Zahrowi. 2009. http://ahmadzahrowi. Wordpress. Com /2009 /03/ 16/descriptive-text/.Html.

Bram, Barli. 1995. Write Well Improving Writing Skills. Yogyakarta: Kanisius.

Byrne, Donn 1980. English Teaching perspective, Singapore: Longman. Unpublished.

Gay, L.R. 1981. Education Research Competences for Analysis and Application. New York: Merrill Publishers Company.

Gould, S. J. 1999. Four Square Writing Method. Carthage, IL: Teaching and Learning Company. Harmer, J. 1987. The Practice of English Language Teaching. New York: Longman Inc.

Heaton, JB. 1988. Writing English Language Tests. New Edition. New York: Longman publishing. 
Lester, F, (Ed.) 2007. Second Handbook of Research on Mathematics Teaching And Learning. Greenwich, CT: information Age.

Lowenberg, P. H. (1991). English as an Additional Language in Indonesia. World Englishes, 10(1), pp. 127-138

McDougal, Little \& Company. 1999. Basic Skill in English. United Stated of America.

Oshima, Alice and Ann Hogue. 1997. Introduction to Academic Writing. London and New York: Longman Group UK Limited.

Pincars. (1987). Definition of Writing. (Online), retrieved from (http:www.text.edu./definition/writing.doc. Accessed on $5^{\text {th }}$ December 2002).

Sangkala, I. (2012). The Correlation between Students' extraversion Personality and Their Writing Skill at Muhammadiyah University of Makassar (a descriptive study). Jurnal Pendidikan Bahasa dan Sastra Inggris, 1(2), 185206.

Sudjana. 1990. Metode Stastistika. Bandung. PT Gramedia.

Syam, U. K., \& Sangkala, I. (2014). Information Transfer Technique in Teaching Writing. Exposure: Jurnal Pendidikan Bahasa dan Sastra Inggris, 3(1), 97106.

Temple, Charles A., Nathan, Ruth., Burris, Nancy., Temple, Frances. (1982). The Beginning of Writing. Second Edition. Copyright by Allyn and Bacon, Inc. United States of America.

Wishon, George and Burks. (1980). Let's Write English. New York: Litton Education Publishing, Inc. 